\title{
EFFECT OF DIFFERENT DIETS ON THE BIOLOGY OF THE ASTIGMATID MITE TYROPHAGUS PUTRESCENTIAE
}

\author{
MOSTAFA, A. M. ${ }^{1}$, HANEM H. I. SAKR ${ }^{2}$, E. M. A, YASSIN ${ }^{1}$, \\ ASMAA R. ABDEL-KHALIK ${ }^{1}$ \\ 1- Acarology Dept. Plant Protection Research Institute, ARC. Dokki, Giza \\ 2- Zoology Dept., Faculty of Science, Menofia University.
}

(Manuscript received 8 October 2013)

\begin{abstract}
This study is conducted to throw some lights on the effect of some food stuffs on the main biological aspects of the acarid mite, T. putrescentiae at $25^{\circ} \mathrm{C}$ and $75 \%$ R.H.. The study indicated that there was a slightly significant difference between the incubation period of $T$. putrescentiae female and food types. The females reached maturity (life cycle) in 11.1, 12.5, 13.3 and 14.0 days when fed on wheat flour, milk powder, fish powder and granular chicken feed, respectively. Female longevity was the longest on wheat flour (39.0 days) while it was recorded the shortest time on fish powder (25.1 days).The female needed 34.6, 30.4, 22.8 and 21.0 days for egg deposition, respectively. The highest number of deposited eggs was recorded on wheat flour (39.0 eggs), while the lowest was on fish powder (27.8 eggs) as feeding source. However, the male life cycle duration was significantly affected by the food type, as it averaged 9.8, 10.3, 12.4 and 13.2 days on the aforementioned diets, respectively. Male adulthood was the longest on wheat flour (28.7 days) while decreased to 17.0 days on fish powder. The male life span lasted 38.5, 34.2, 31.2 and 30.2 days, when fed on the above mentioned diets, respectively.
\end{abstract}

\section{INTRODUCTION}

The acarid mite $T$. putrescentiae (Schrank) infest a wide range of foodstuffs, plant and animal materials where environmental conditions are suitable, and is considered to be a cosmopolitan stored product pest of significant economic and sanitary importance. T. putrescentiae is most frequently found in stored food with a relatively high fat and protein content, such as wheat and soy, flour, cheese, rye bread, herring meal, bacon, dried milk and various seeds (Duek et al., 2001). The relative humidity of the micro-environment as well as temperature and food sources are the main ecological factors affecting the growth and development of mites. The biology and reproductive rates of $T$. putrescentiae have been studied under different temperatures and humidities and on different feeding sources, Barker, 1967, Sinha and Mills 1968, Bilgrami and Tahseen 1992, Ottoboni et al., 1993, Sánchez-Ramos and Castañera 2001, Mohamed 2003, Kheradmand et al., 2007 and Sarwar et al., 2010. However, this study is conducted to throw lights on the effect of some food stuffs (wheat flour, milk powder, fish powder and granular chicken feed) on the main biological aspects of the acarid mite, T. putrescentiae at $25 \pm 2{ }^{\circ} \mathrm{C}$ and $75 \pm 5 \%$ R.H. 


\section{MATERIALS AND METHODS}

T. putrescentiae reared on four different freshly materials (wheat flour, dried milk, fish powder and granular chicken feed) under laboratory constant conditions ( $25 \pm 2{ }^{\circ} \mathrm{C}$ and $70 \pm 5 \%$ R.H.). Mite larvae were reared individually on each feeding source in Petri dishes (9 cm diam.) and observed every $12 \mathrm{~h}$. until maturation. As soon as females emerged, males were introduced for mating. Eggs were collected during $12 \mathrm{~h}$. postoviposition. Eggs were solitary placed into glass rings with the aid of camel hair brush and incubated at the same conditions mentioned above. Fifteen eggs were used per each rearing material and observed every $12 \mathrm{~h}$. until hatching and mite become mature. Eggs laid by each female mite were counted daily until female died. At each rearing host, the incubation period, immature stages, life cycle, longevity of males and females and fecundity (total number of eggs laid per female) were calculated. All presented data were subjected to one way of variance (ANOVA) and means were separated by Duncan's multiple range test, (Duncan ,1955).

\section{RESULTS AND DISCUSSION}

Feeding behavior: The acarid mite, $T$. putrescentiae possesses a few teeth on the fixed digit and movable digit chelicerae seems to be more adapted for cutting and biting a characteristic feature of fungivorous and granivorous or omnivorous mites (Woolley, 1988).

Hatching, moulting and mating: Eggs of T. putrescentiae are ovoid, globular or elliptical. The eggs are whitish in color. Before incubation, the embryo grows gradually in size and whitish small larvae hatches. Immature stages of this species (larva and 2 nymphs) searche for a suitable place, then stop movement and feeding, extending their forelegs forwards and the hind legs backwards (quiescent stage). At the end of this period, moulting occurs. After emergence of the adult male and female stages, mating process occurred immediately in which the male clings over the female dorsum with their opisthosoma opposite to each other, and firmly seizing the female with hind legs. The mating process lasted about 5-7 minutes.After copulation, both sexes separate and female accepts more mating.

Biological aspects: This work aimed to study the effect of different food types on the biological aspects of the mite, T. putrescentiae at $25 \pm 2^{\circ}$ C.and $75 \pm 5 \%$ R.H.

\section{Female:}

1. a. Incubation period: Table (1) cleared that there was slightly differences between the incubation period of $T$. putrescentiae female when fed on different food types. This period averaged 3.1, 3.3, 3.6 and 4.0 days for eggs which gave rise of female when reared on wheat flour, milk powder, granular chicken feed and fish 
powder, respectively. The statistical analysis of obtained data indicated that L.S.D. at $0.05=0.384$.

1. b. Immature stages: As shown in Table (1), the immature stages of $T$. putrescentiae female took 8.0, 9.2, 9.7 and 10.0 days when fed on the same trend of food mentioned before, respectively.The statistical analysis of obtained data indicated that there were highly significant differences between the individuals when fed on different diets. L.S.D. at $0.05=0.115$.

1. c. Life cycle: Regarding to the life cycle, Table (1) cleared that $T$. putrescentiae female reached maturity in $11.1,12.5,13.3$ and 14.0 days when the individuals fed on the same food sources, respectively. The same data denoted also that wheat flour shorten the life cycle while feeding on fish powder prolonged this period. The L.S.D. at 0.05 level I = 0.264 .

1. d. Longevity: T. putrescentiae adult female longevity, Table 1, differed on the different tested food, reached to the highest duration on wheat flour 39.0 days and lowest on fish powder ( 25.1 days).This means that wheat flour was the most favorable diet while the least was fish powder. However, the mite lasted in this period 34.7 days on milk powder and 27.3 days when reared on granular chicken feed. L.S.D. at 0.05 level = 0.715 .

1. e. Life span: T. putrescentiae life span, was highly affected by the types of food. The female life span took 50.1, 47.2, 40.3 and 39.1 days when the mites fed on wheat flour, milk powder, granular chicken feed and fish powder, respectively, Table (1), L.S.D. at 0.05 level $=0.864$.

1. f. Pre-oviposition, oviposition and post-oviposition periods: The obtained Table (2) showed that the pre-oviposition period of $T$. putrescentiae was not affected by the type of used diets and this period was about 2 days. The adult mite female needed 34.6, 30.4, 22.8 and 21.0 days for egg deposition when fed on wheat flour, milk powder, granular chicken feed and fish powder, respectively.On the other hand, the post-oviposition period took 2.6, 2.1, 2.6 and 2.2 days on the above mentioned diets, respectively. The statistical analysis of obtained data indicated that L.S.D. at 0.05 level was $0.269,0.294$ and 0.164 for pre-oviposition, oviposition and post-oviposition period, respectively,

1. g. Fecundity: Table (2) denoted that the type of used feeding sources significantly affected female fecundity (no. of eggs). The highest deposited eggs was found when female fed on wheat flour (39.0 eggs), while lowest was on fish powder (27.8 eggs). However, the female deposited 34.0 eggs on milk powder and 30.0 eggs on granular chicken feed. The study showed that L.S.D. at 0.05 was 1.102 . Generally, the best host for feeding $T$. putrescentiae was wheat flour which increased the number of deposited eggs, but the lowest favorable one was fish powder. 


\section{Male:}

2. a. Incubation period: The incubation period of $T$. putrescentiae male lasted 2.6, 3.0, 3.4 and 3.7 days when fed on wheat flour, milk powder, granular chicken feed and fish powder, respectively, Table (3). It was significantly affected by the food type. The statistical analysis of current data dented that L.S.D. at 0.05 level = 0.118 .

2. b. Immature stages: The data presented in Table (3) revealed that the immature stages of $T$. putrescentiae lasted 7.2, 7.3, 9.0 and 9.5 days, when the same diets mentioned before used, respectively. L.S.D. $=0.360$.

2. c. Life cycle: In the current investigation, the male life cycle is completed in 9.8 , $10.3,12.4$ and 13.2 days when the males reared on the aforementioned diets, respectively, Table (3). This indicated that the type of food significantly affected male life cycle, L.S.D. at 0.05 level $=0.288$.

2. d. Longevity: Table (3) cleared that longevity of males was obviously affected by the type of used food. Male longevity averaged the highest duration on wheat flour (28.7 days) and decreased to 17.0 days when the fish powder was used. This means that the wheat flour was the best diet, but the fish powder was the least favorable one. The longevity on milk powder and granular feed took 23.9 and 18.8 days, respectively.

2. e. Life span: During the course of the present investigation, the life span of $T$. putrescentiae male durated $38.5,34.2,31.2$ and 30.2 days, when fed on the same order of feeding source, respectively, Table (3).

Effect of different factors (sex and diet) on the biological aspects of $\boldsymbol{T}$. putrescentiae: The current study, Table (4), indicated that (incubation period, life cycle, longevity and life span) of $T$. putrescentiae females and males were highly affected by the different types of food. The statistical analysis of the obtained data showed that L.S. D. at 0.05 level was 0.072 and 0.102 in case of incubation period for the effect of sex and diet on this period, respectively. However, L.S. D. was $0.253 \& 0.358,0.529 \& 0.748$ and $0.559 \& 0.791$ in case of life cycle, longevity and life span, respectively. Although $T$. putrescentiae was previously described as saprophagous species (Hughes, 1976), its attraction to, and successful completion of life cycle exclusively on wheat flour, milk powder, granular chicken feed and fish powder, suggests frequent utilization of this food resource under natural conditions. The results obtained by Chmielewski (1999) showed that bruised buckwheat was accepted as food by the mould mite, T. putrescentiae which allows completing its development and multiplication. The life cycle was 16.9 days and the high fecundity indicated that bruised buckwheat seems to be most favorable medium for rearing this mite. Also, similar results were obtained by Kheradmand et al., (2007), where they noticed that the pre-oviposition period of T. putrescentiae 
was not influenced by the species of mushroom, but the other reproductive periods showed significant changes and female longevity was influenced by food type. Sarwar et al., (2010) mentioned that the assessment of macronutrients in soybean, maize, and wheat flours showed that wheat had more carbohydrate and ash but reduced protein and fat contents and merits as leading compound in supporting higher T. putrescentiae populations.

Table 1. Effect of different diets on female biological aspects of the acarid mite, $T$. putrescentiae at $25^{\circ} \mathrm{C}$ and $75 \%$ R.H.

\begin{tabular}{|c|c|c|c|c|c|}
\hline \multirow{2}{*}{$\begin{array}{c}\text { Biological } \\
\text { aspect }\end{array}$} & \multicolumn{4}{|c|}{ Diet } & \multirow{2}{*}{$\begin{array}{l}\text { L.S.D. } \\
\text { at } \\
0.05\end{array}$} \\
\hline & Wheat flour & Milk powder & $\begin{array}{c}\text { Granular chicken } \\
\text { feed }\end{array}$ & $\begin{array}{c}\text { Fish } \\
\text { powder }\end{array}$ & \\
\hline Incubation & $\begin{array}{c}3.1 \pm 0.13^{c} \\
(3-3.3)\end{array}$ & $\begin{array}{c}3.3 \pm 0.17^{a b} \\
(3-3.5)\end{array}$ & $\begin{array}{l}3.6 \pm 0.11^{b} \\
(3.4-3.7)\end{array}$ & $\begin{array}{l}4.0 \pm 0.1^{a} \\
(3.7-3.8)\end{array}$ & 0.384 \\
\hline $\begin{array}{l}\text { Immature } \\
\text { stages }\end{array}$ & $\begin{array}{c}8.0+0.21^{d} \\
(8-8.5)\end{array}$ & $\begin{array}{l}9.2 \pm 0.41^{\mathrm{c}} \\
(9.0-9.9)\end{array}$ & $\begin{array}{l}9.7 \pm 0.11^{b} \\
(9.6-9.8)\end{array}$ & $\begin{array}{c}10.0+0.08 \\
\frac{a}{(9.4-9.8)}\end{array}$ & 0.115 \\
\hline Life cycle & $\begin{array}{l}11.1+0.14^{\mathrm{d}} \\
(10.8-11.3)\end{array}$ & $\begin{array}{c}12.5+0.71^{\mathrm{c}} \\
(11-13)\end{array}$ & $\begin{array}{c}13.3+0.45^{b} \\
(14-15)\end{array}$ & $\begin{array}{c}14.0+0.41^{a} \\
(16.5- \\
17.5)\end{array}$ & 0.264 \\
\hline Longevity & $\begin{array}{c}39.0 \pm 1.14^{a} \\
(38-41)\end{array}$ & $\begin{array}{c}34.7 \pm 0.71^{b} \\
(33-35)\end{array}$ & $\begin{array}{c}27.3 \pm 0.71^{c} \\
(26-28)\end{array}$ & $\begin{array}{c}25.1 \pm 0.71^{d} \\
(24-26)\end{array}$ & 0.715 \\
\hline Life span & $\begin{array}{l}50.1+1.27^{a} \\
(46.8-50.2)\end{array}$ & $\begin{array}{c}47.2+0.89^{b} \\
(44-46)\end{array}$ & $\begin{array}{c}40.3+0.45^{d} \\
(41-42)\end{array}$ & $\begin{array}{c}39.1 \pm 0.96^{\mathrm{c}} \\
(40.5- \\
43.0)\end{array}$ & 0.864 \\
\hline
\end{tabular}

Means in the same column followed by the same letters were not significantly different at $5 \%$ level.

Table 2. Effect of different diets on female longevity and fecundity of the acarid mite, T. putrescentiae at $25^{\circ} \mathrm{C}$ and $75 \%$ R.H.

\begin{tabular}{|c|c|c|c|c|c|}
\hline \multirow{2}{*}{$\begin{array}{l}\text { Biological } \\
\text { aspect }\end{array}$} & \multicolumn{4}{|c|}{ Diet } & \multirow[b]{2}{*}{$\begin{array}{l}\text { L.S.D. at } \\
0.05\end{array}$} \\
\hline & $\begin{array}{l}\text { Wheat } \\
\text { flour }\end{array}$ & Milk powder & $\begin{array}{c}\text { Granular } \\
\text { chicken feed }\end{array}$ & $\begin{array}{c}\text { Fish } \\
\text { powder }\end{array}$ & \\
\hline $\begin{array}{l}\text { Pre-oviposition } \\
\text { period }\end{array}$ & $\begin{array}{c}2.0 \pm 0.2 \\
a \\
(2.0- \\
2.5)\end{array}$ & $\begin{array}{l}2.2 \pm 0.1^{a} \\
(2.0-2.2)\end{array}$ & $\begin{array}{l}2.0 \pm 0.3^{\mathrm{a}} \\
(1.5-2.5)\end{array}$ & $\begin{array}{l}1.9 \pm 0.2^{a} \\
(1.5-2.0)\end{array}$ & 0.269 \\
\hline $\begin{array}{l}\text { Oviposition } \\
\text { period }\end{array}$ & $\begin{array}{c}34.6+0 . \\
9^{a} \\
(33.5- \\
35.5)\end{array}$ & $\begin{array}{l}30.4+0.3^{b} \\
(28.9-31)\end{array}$ & $\begin{array}{l}22.8+0.6^{c} \\
(22-23.5)\end{array}$ & $\begin{array}{l}21.0 \pm 0.5 \\
d \\
(20.5- \\
22)\end{array}$ & 0.294 \\
\hline $\begin{array}{l}\text { Post-oviposition } \\
\text { period }\end{array}$ & $\begin{array}{c}2.6+0.4 \\
(2-3)\end{array}$ & $\begin{array}{c}2.1 \pm 0.2^{b} \\
(2-2.5)\end{array}$ & $\begin{array}{c}2.6 \pm 0.5^{a} \\
(2-3)\end{array}$ & $\begin{array}{l}2.2 \pm 0.0 \\
(2-2.1)\end{array}$ & 0.164 \\
\hline Fecundity & $\begin{array}{c}39.0 \pm 1 \\
3^{\frac{a}{a}} \\
(38-41)\end{array}$ & $\begin{array}{c}34.0 \pm 1.5^{b} \\
(32-36)\end{array}$ & $\begin{array}{c}30.0 \pm 0.7^{c} \\
(29-31)\end{array}$ & $\begin{array}{l}27.8 \pm 0.7 \\
\text { d } \\
(27-29)\end{array}$ & 1.102 \\
\hline
\end{tabular}

Means in the same column followed by the same letters were not significantly different at $5 \%$ level. 
Table 3. Effect of different diets on male biological aspects of T. putrescentiae at $25^{\circ} \mathrm{C}$ and $75 \%$ R.H.

\begin{tabular}{|c|c|c|c|c|c|}
\hline \multirow{2}{*}{$\begin{array}{c}\text { Biological } \\
\text { aspect }\end{array}$} & \multicolumn{4}{|c|}{ Diets } & \multirow{2}{*}{$\begin{array}{l}\text { L.S.D. at } \\
0.05 \text { level }\end{array}$} \\
\hline & $\begin{array}{l}\text { Wheat } \\
\text { flour }\end{array}$ & $\begin{array}{c}\text { Milk } \\
\text { powder }\end{array}$ & $\begin{array}{c}\text { Granular } \\
\text { chicken feed }\end{array}$ & $\begin{array}{c}\text { Fish } \\
\text { powder }\end{array}$ & \\
\hline Incubation & $\begin{array}{l}2.6 \pm 0.13^{d} \\
(2.3-2.9)\end{array}$ & $\begin{array}{c}3.0 \pm 0.08^{c} \\
(3-3.2)\end{array}$ & $\begin{array}{l}3.4 \pm 0.9^{b} \\
(3.3-3.5)\end{array}$ & $\begin{array}{l}3.7 \pm 0.05^{\mathrm{a}} \\
(3.0-4.2)\end{array}$ & 0.118 \\
\hline $\begin{array}{c}\text { Immature } \\
\text { stages }\end{array}$ & $\begin{array}{c}7.2 \pm 0.05^{d} \\
(7.0-7.4) \\
\end{array}$ & $\begin{array}{l}7.3 \pm 0.11^{\mathrm{c}} \\
(8.4-8.7)\end{array}$ & $\begin{array}{l}9.0 \pm 0.09^{\mathrm{b}} \\
(8.9-9.2)\end{array}$ & $\begin{array}{l}9.5 \pm 0.18^{\mathrm{a}} \\
(9.2-9.8) \\
\end{array}$ & 0.360 \\
\hline Life cycle & $\begin{array}{l}9.8 \pm 0.26^{d} \\
(9.0-10.2) \\
\end{array}$ & $\begin{array}{l}10.3 \pm 0.45^{c} \\
(9.5-10.8)\end{array}$ & $\begin{array}{r}12.4 \pm 0.04^{b} \\
(12.0-13) \\
\end{array}$ & $\begin{array}{l}13.2 \pm 0.27^{a} \\
(13.0-13.6) \\
\end{array}$ & 0.288 \\
\hline Longevity & $\begin{array}{c}28.7 \pm 0.84^{\mathrm{a}} \\
(28-30)\end{array}$ & $\begin{array}{c}23.9 \pm 0.84^{b} \\
(23-25)\end{array}$ & $\begin{array}{c}18.8 \pm 0.84^{c} \\
(18-20)\end{array}$ & $\begin{array}{c}17.0 \pm 0.71^{\mathrm{d}} \\
(16-18)\end{array}$ & 0.260 \\
\hline Life span & $\begin{array}{l}38.5 \pm 0.81^{a} \\
(34.8-37.0)\end{array}$ & $\begin{array}{c}34.2 \pm 0.89^{b} \\
(33-35)\end{array}$ & $\begin{array}{c}31.2 \pm 0.83^{d} \\
(31-32)\end{array}$ & $\begin{array}{l}30.2 \pm 0.57^{c} \\
(30-32.9)\end{array}$ & 0.523 \\
\hline
\end{tabular}

Means in the same column followed by the same letters were not significantly different at $5 \%$ level.

Table 4. Effect of different factors (sex and diet) on the biological aspects of $T$. putrescentiae at $25^{\circ} \mathrm{C}$ and $75 \%$ R.H.

\begin{tabular}{|c|c|c|c|c|c|}
\hline \multirow{2}{*}{$\begin{array}{c}\text { Biological } \\
\text { aspect }\end{array}$} & \multirow[t]{2}{*}{ Source } & \multirow[t]{2}{*}{$\mathrm{F}$} & \multirow[t]{2}{*}{$P$} & \multicolumn{2}{|c|}{ L.S.D. at 0.05 level } \\
\hline & & & & Sex & Diet \\
\hline \multirow[t]{3}{*}{ Incubation } & Sex & 50.00 & $0.000 * * *$ & \multirow[t]{3}{*}{0.072} & \multirow[t]{3}{*}{0.102} \\
\hline & Diet & 130.56 & $0.000 * * *$ & & \\
\hline & Int. sex $x$ diet & 4.13 & $0.0139 *$ & & \\
\hline \multirow[t]{3}{*}{ Life cycle } & Sex & 183.33 & $0.000 * * *$ & \multirow[t]{3}{*}{0.253} & \multirow[t]{3}{*}{0.358} \\
\hline & Diet & 841.93 & $0.000 * * *$ & & \\
\hline & Int. sex $x$ diet & 3.24 & $0.0349 *$ & & \\
\hline \multirow[t]{3}{*}{ Longevity } & Sex & 1267.59 & $0.000 * * *$ & \multirow[t]{3}{*}{0.529} & \multirow[t]{3}{*}{0.748} \\
\hline & Diet & 526.06 & $0.000 * * *$ & & \\
\hline & Int. sex $x$ diet & 6.65 & $0.0013 * *$ & & \\
\hline \multirow[t]{3}{*}{ Life span } & Sex & 1560.36 & $0.000 * * *$ & \multirow[t]{3}{*}{0.559} & \multirow[t]{3}{*}{0.791} \\
\hline & Diet & 82.65 & $0.000 * * *$ & & \\
\hline & Int. sex $x$ diet & 9.17 & $0.0002 * * *$ & & \\
\hline
\end{tabular}

$*$ s significant $\quad * *=$ highly significant $\quad * * *=$ very highly significant 


\section{REFERENCES}

1. Barker, P. S. 1967. The effects of high humidity and different temperatures on the biology of Tyrophagus putrescentiae (Schrank) (Acari: Tyroglyphidae). Canad. J. Zool., 45 (1): 91-96.

2. Bilgrami, A. L. and Q. Tahseen 1992. A nematode feeding mite, Tyrophagus putrescentiae (Sarcoptiformes: Acaridae).Fund.and App. Nemat., 15(5):477-478.

3. Chmielewski, W. 1999. Acceptance of buckwheat grain as a food by Tyrophagus putrescentiae (Schrank) (Acari: Acaridae). Fagoyrum, 16:95-97.

4. Duek, L., G. Kaufman, E. Palevsky and I. Bericevsky 2001. Mites in fungal cultures. Mycoses, 44 (9-10):390-394.

5. Duncan, D. B. 1955: Multiple range and multiple F.test. Biometrics, 11: 1-42

6. Hughes, A. M. 1976. The mites of stored food products and houses. Tech. Bull., Min. Agric. and Fisheries in London, 63: 105 - 110.

7. Kheradmand, K., K. Kamali, Y. Fathipour and E. M. Goltapeh 2007. Development, life table and thermal requirement of Tyrophagus putrescentiae (Astigmata: Acaridae) on mushrooms. J. Stored Products Res., 43, (3): 276-281.

8. Mohamed, A. A. 2003.Studies on some mites associated with cereals and stored products in Egypt. M.Sc. Thesis, Fac. Sci. (Girls), Al-Azhar Univ., 103 pp.

9. Ottoboni, F., S. Mazzuccato, I. E. Rigamonti and G. C. Lozzia.1993.Mites infesting flour and malt. Tec. Molitoria, 44 8): 673-676.

10. Sánchez-Ramos I. and P. Castañera 2001.Development and survival of Tyrophagus putrescentiae (Acari: Acaridae) at constant temperatures. Environ. Entomol., 30 (6):1082-1089.

11. Sarwar, M, X. Xuenong and W. Kongming 2010. Effects of different flour on the biology of the prey Tyrophagus putrescentiae (Schrank) (Acarina: Acaridae) and the predator Neoseiulus pseudolongispinosus (Xin, Liang and Ke) (Acari:Phytoseiidae). International J. Acar., 36(5):363-369.

12. Sinha, R. N. and J. T. Mills 1968. Feeding and reproduction of the grain Mite and the Mushroom mite on some species of Penicillium ecosystems researches on population. Ecology. 32 (1): 33- 46.

13. Woolley, T. A. 1988. Acarology Mites and human welfare. Jhon Wiley and Sons, New York, pp. 86-93. 


\title{
تاثير الاغذية المختلفة على بيولوجيا الاكاروس عديم الثغز (Acarin )
}

\section{Tyrophagus putrescentiae (Schrank) (Acarina :Acaridae)}

\author{
عادل محمود مصطفى' ، هانم حامد (بر اهيم صقر ' ،

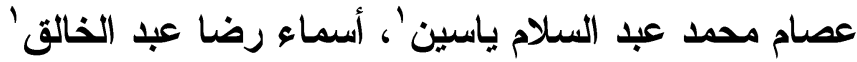 \\ ا - معه بحوث وقاية النباتات - مركز البحوث الزر/عية - الدقى - هبزة - مصر.

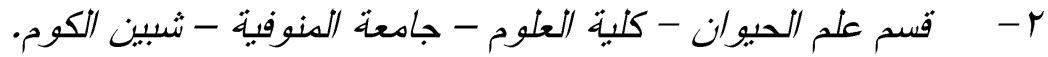

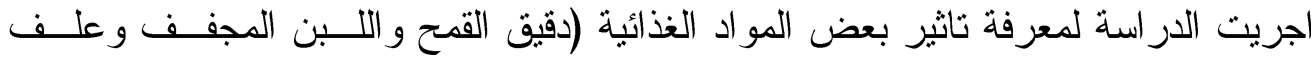

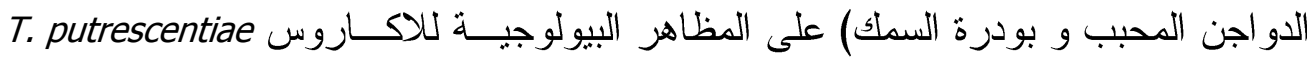

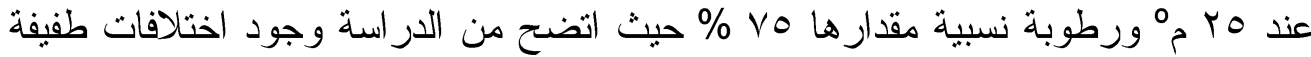

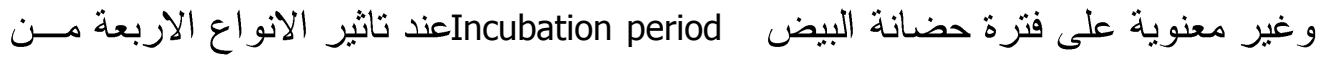
الاغذية على انثى الاكاروس. كما أوضحت ان الاناث قد وصلت وصلت الى الطور البالغ بعد فترة مقدارها , 11, (life cycle) الافر اد البالغة (Longevity) للاناث قد تاثرت بشكل واضح حيث وصلت الى اعلى معدل لها

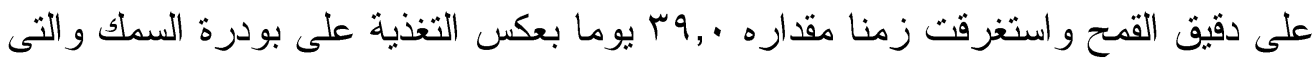

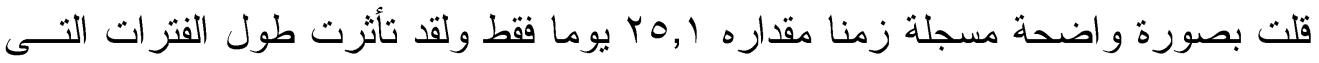

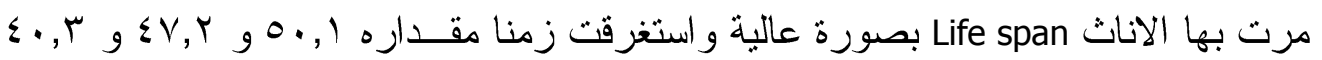

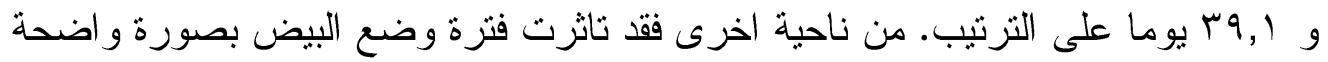

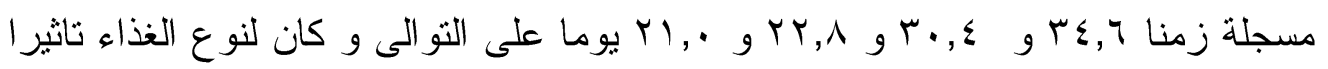

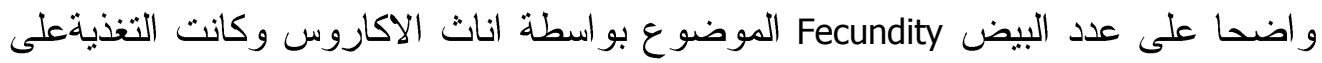

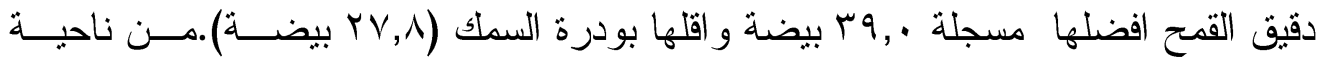

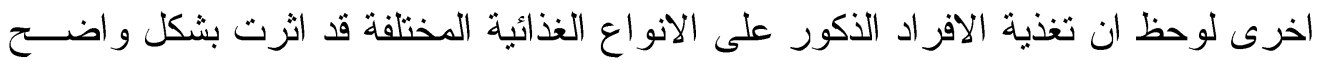
على الفتر ات المختتلفة من حباة الاكاروس ولوحظ ان كل الفتر ات التى مرت بهــــا الـــكور التهر كانت اقل من التى سجلت للاناث وظهرت اختلافات طفيفة وغير معنوية على فترة حضانة

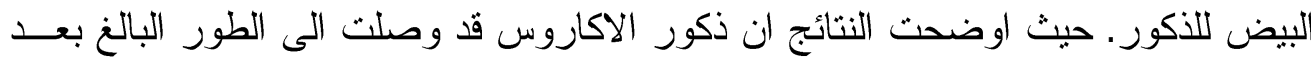

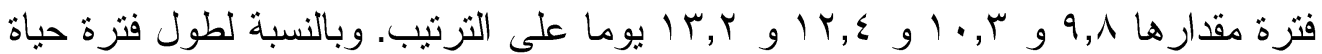

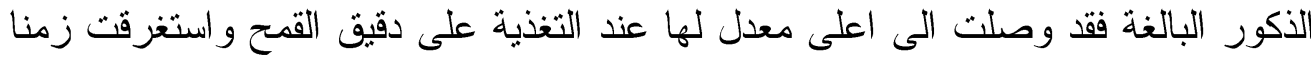

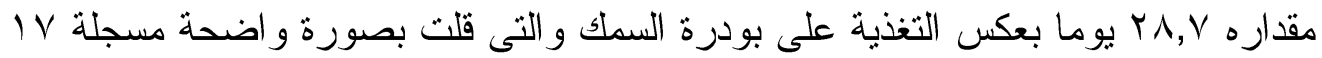

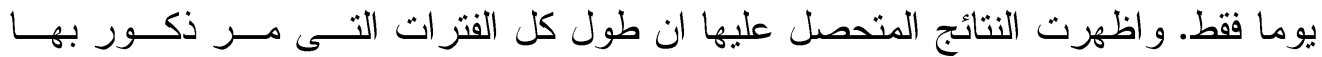

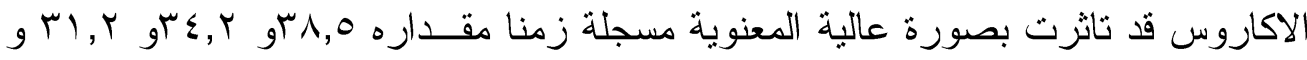

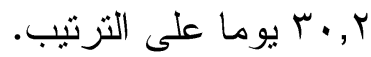

